\title{
MUDPOTS AT STEFANOS HYDROTHERMAL CRATER OF NISYROS VOLCANO. AN INSIGHT AT THE HYDROTHERMAL PROCESSES OF AN ACTIVE VOLCANO
}

\author{
Kanellopoulos C. . $^{*}$ and Xirokostas $\mathbf{N}^{\mathbf{2}^{*}}$ \\ ${ }^{l}$ Geologist,Ph.D., ckanellopoulos@gmail.com \\ ${ }^{2}$ Chemical Engineer, Ph.D., nikosxirokostas@yahoo.com \\ *Institute of Geology and Mineral Exploration, $1^{\text {st }}$ Spirou Louis St., Olympic Village, 13677, \\ Acharnae, Greece
}

\begin{abstract}
On Nisyros island as a result of the volcanic activity and active tectonic, a hydrothermal system develops and it is expressed by 5 types of surface manifestations: i) thermal springs, ii) fumaroles iii) hydrothermal craters, iv) hot grounds and v) mudpots. In general, a mudpot could be described as an acidic hot spring and fumarole with limited water which it is formed in high-temperature geothermal areas. Water sample and depositions of mudpots collected, analyzed and studied from Stefanos hydrothermal crater, which is the only site on Nisyros Island, where mudpots occur. Mudpots water is very acidic $(\mathrm{pH}=2.4)$, with high sulfate concentration $(1375 \mathrm{mg} / \mathrm{L})$, due to the $\mathrm{H}_{2} \mathrm{~S}_{(\mathrm{gas})}$ and temperature near the boiling point. As a result, elemental sulfur is found inside the depositions alongside with products of the hydrothermal alteration of the surrounding rocks. In the water and in the depositions were found high concentrations in several elements (e.g. in water: $55 \mathrm{mg} / \mathrm{L} \mathrm{Fe}$; $19.5 \mathrm{mg} / \mathrm{L} \mathrm{Zn}$, in depositions: $430 \mathrm{mg} / \mathrm{Kg} \mathrm{Pb} ; 72 \mathrm{mg} / \mathrm{Kg} \mathrm{Cu} ; 60 \mathrm{mg} / \mathrm{Kg} \mathrm{Cr}$ ) reflecting the alterations processes which are taking place.
\end{abstract}

Keywords: mudpots, hydrothermal systems, volcano, Nisyros, Greece.

\section{Пєрі́ $\eta \psi \eta$}

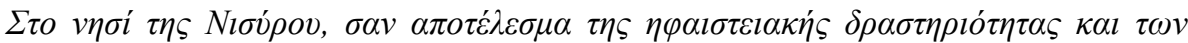

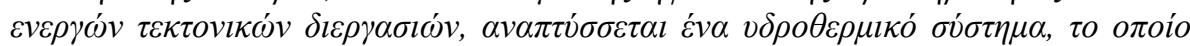

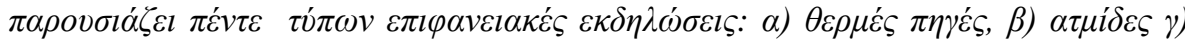

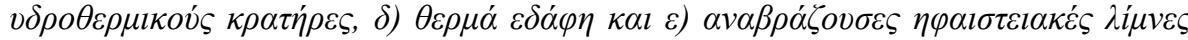

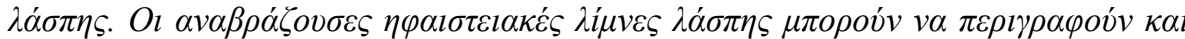

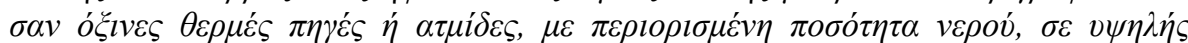

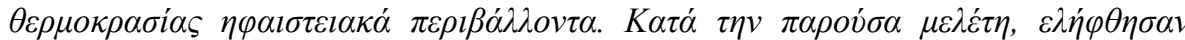

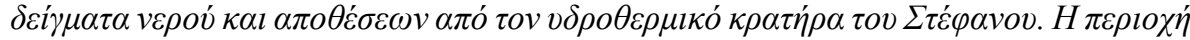

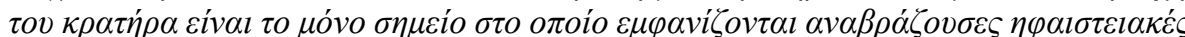

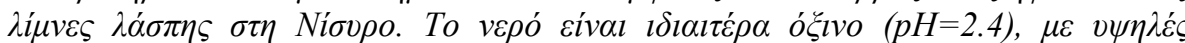

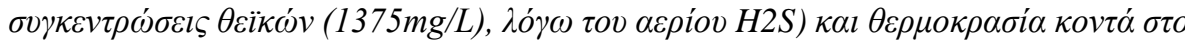

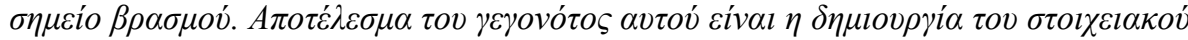

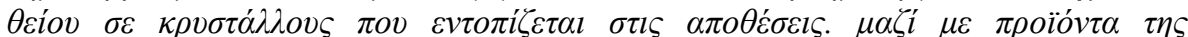

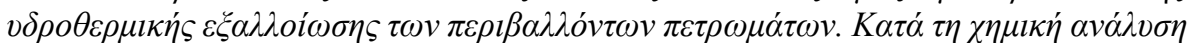

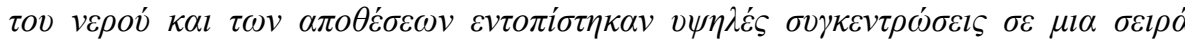




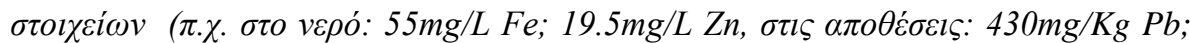

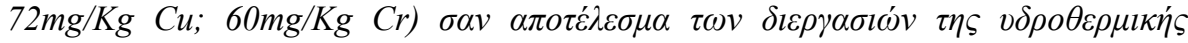

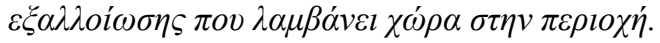

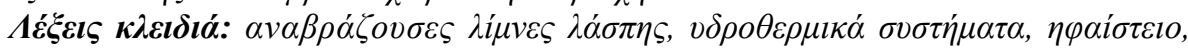

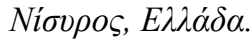

\section{Introduction}

Nisyros Island is located in southeastern part of Aegean Sea and geologically belongs to the South Aegean active volcanic arc. The whole island forms a calc-alkaline stratovolcano, which is built at various explosive activities in the last 150,000 years; it has a $3.8 \mathrm{~km}$ diameter caldera (Di Paola, 1974; Keller et al., 1990; Vougioukalakis, 1993; Francalanci et al., 1995) and is currently classified in the "Very High Threat" category (Kinvig et al., 2010).

As a result of the volcanic activity and active tectonic, a hydrothermal system occurs. The presence of hydrothermal activity on Nisyros is expressed by five types of surface manifestations: i) the thermal springs distributed along the northern and southern coasts of the island, ii) the large fumarolic field located mainly in the southern Lakki plain, iii) the hydrothermal craters, iv) the hot grounds and v) the mudpots located in the center of Stefanos hydrothermal crater (Fig. 1, 2). In the Lakki area, different hydrothermal eruptions took place recently until the historical times (Marini et al., 1993). Also, changes in the composition of the fumaroles recorded recently (1995-1998) and they were associated with episodes of intense seismicity and ground deformation (Chiodini et al., 2002; Caliro et al., 2005; Shimizu et al., 2005), during a volcanic unrest period.

In general, mudpot or mud pool could be described as an acidic hot spring or a fumarole with limited water. It usually takes the form of a pool of bubbling mud. The acid fluids and microorganisms alter the surrounding rock into clay and mud. The mud of a mudpot usually takes the form of a viscous, often bubbling slurry. As the boiling mud is often squirted over the brims of the mudpot, a sort of mini-crater of mud could build up (Clynne et al., 2003).

Mudpots are forming high-temperature geothermal areas where water is in short supply. The little water that is available rises to the surface usually at spots where are rich in volcanic ash, clay and other fine particulates. The thickness of the mud usually changes along with meteoric phenomena, i.e. rain. On Nisyros Island mudpots were detected only at Stefanos hydrothermal crater (Fig. 2) and their size depends on climate conditions i.e. the rain in the Stefanos and surrounding plain and caldera area.

The aim of this paper is to study the chemical composition of the mudpots and the mineralogical and geochemical composition of their depositions and relate them with the hydrothermal processes of Nisyros volcano.

\section{Geological setting}

Nisyros island (42 $\mathrm{km}^{2}$ in surface) is a small and young composite volcano with a central caldera (Keller, 1971; Di Paola, 1974; Vougioukalakis, 1984, 1993; Limburg, 1986; Limburg et al., 1986; Bohla and Keller, 1987; Lodise, 1987; Seymour and Vlassopoulos, 1992; Wyers and Barton, 1989; Keller et al., 1990; Papanikolaou et al., 1991; Limburg and Varekamp, 1991; Gansecki, 1991; Francalanci et al., 1995; Volentik et al., 2002) (Fig. 1). The topography resembles the shape of a truncated cone with a basal diameter of $8 \mathrm{Km}$ and a central caldera depression of $4 \mathrm{Km}$ diameter. The post-caldera domes (youngest volcanic products) excel the caldera rim ( $450 \mathrm{~m}$ high) and the internal domes arrive at a maximum height of $698 \mathrm{~m}$. The whole island is entirely buildup of volcanic products, deposited on a basement consisting of Mesozoic limestone and Neogene sediments (Barberi et al., 1988; Varekamp, 1992; Nis-1 well report - Geotermica Italiana, 1983). 
Two eruptive cycles are distinguished in the evolution of Nisyros volcanic activity: the first cycle includes the cone-building eruptive activity and the second one the caldera-forming eruptive activity. The second cycle consists of two different phases. Each phase commenced with a low intensity - low magnitude phreato-magmatic explosion fed by rhyolitic magmas. This triggered a central calderic collapse that was followed by extrusion of rhyolitic-dacitic domes and lava flows.

The existing radiometric ages $\left(\mathrm{K}-\mathrm{Ar},{ }^{14} \mathrm{C}\right)$, tephro-stratigraphy and the absence of the Kos Plateau Tuff deposits suggest that the actual subaerial part of Nisyros was built up during the last 160,000 years. The available radiometric ages of Nisyros rocks are difficult to correlate and still leave some open questions about the time frame of volcanic eruption. K/Ar ages of 66.4 and $24 \mathrm{ka}$ were obtained on the uppermost products of the cone building activity (Rehren, 1988). According to these data, the earliest caldera collapse should have an age $<24 \mathrm{ka}$. Nevertheless, ages $>44$ ka were obtained with different methods for the Nisyros Upper Pumice deposits, whereas the age of the Yali Upper Pumice that postdate the last Nisyros caldera collapse is $31 \mathrm{ka}$ (Yali C deep ash layer of Federman and Carey, 1980).

All the historically registered explosions at Nisyros (1873-1887) are hydrothermal and created three small craters in the west area of the caldera floor (Gorceix, 1873, 1874; Martelli, 1917). The presence of more than 8 older hydrothermal explosion craters in the caldera floor, with a maximum diameter of $300 \mathrm{~m}$, indicate that this type of activity was frequent in the past few thousand years. The island is today a site of intense hydrothermal activity which feed many fumaroles in the caldera floor area and hot springs along the coast, hosting a high enthalpy geothermal field (fluids with more than $400^{\circ} \mathrm{C}$ at $1800 \mathrm{~m}$ depth; Geotermica Italiana, 1983).

Active tectonics is prominent on the Nisyros island group. Some of the active faults have been reactivated during seismic crisis manifested in the last century. During the last 1995-1997 volcanic unrest shallow earthquake activity, two of these fractures trending N-S and NW-SE were opened on Nisyros and Yali, respectively (Vougioukalakis et al., 1998).

Nisyros is characterised by a nearly continuous series of rocks, from basaltic andesites to rhyolites. Basaltic andesites and most of andesites are CA, whereas dacites and rhyolites plot along the boundary between CA and HKCA series.

\section{Materials and methods}

\subsection{Groundwater and depositions sampling and analysis}

From mudpots, which are located at the Eastern part of Stefanos hydrothermal crater (Fig. 2), one hot groundwater sample and several wet and dry samples from the depositions were collected. The groundwater sample was vacuum filtered and stored in polyethylene bottles and preserved in a refrigerator. Part of it was acidified to a final concentration of $2 \%$ nitric acid. Sampling was conducted on June 2015.

About the groundwater sample, the major elements and ion concentrations were measured by spectrophotometry, or/and titration or/and AAS or and ICP-OES (Table 1). The trace element concentrations were measured using ICP-MS (Table 1).

Depositions from active (wet) and dry mudpots were collected. The deposition samples were dried in an oven at a temperature of $40^{\circ} \mathrm{C}$ and afterwards pulverized to $<200$ mesh in an agate mill. Representative samples were digested with a mixture of $\mathrm{HCl}-\mathrm{HNO}_{3}-\mathrm{HF}$ acids and were analysed for a series of trace elements by ICP-MS and a series of major elements by ICP-OES after fusion. In order to determine the mineralogical composition of the samples, a number of thin sections were prepared and investigated under optical microscope and powder X-ray diffraction (XRD) analyses were conducted. The XRD study was carried out using a Philips X'Pert Panalytical X-ray diffractometer, operating with $\mathrm{Cu}$ radiation at $40 \mathrm{kV}, 30 \mathrm{~mA}, 0.020^{\circ}$ step size and $1.0 \mathrm{~s}$ steptime. The XRD patterns were evaluated using the EVA ver. 11 software. All samples were analyzed in the Laboratories of Institute of Geology and Mineral Exploration (I.G.M.E.) in Athens. 




Figure 1 - 3D simplified geological map of Nisyros Island (Vougioukalakis and Androulakakis, 2008). 

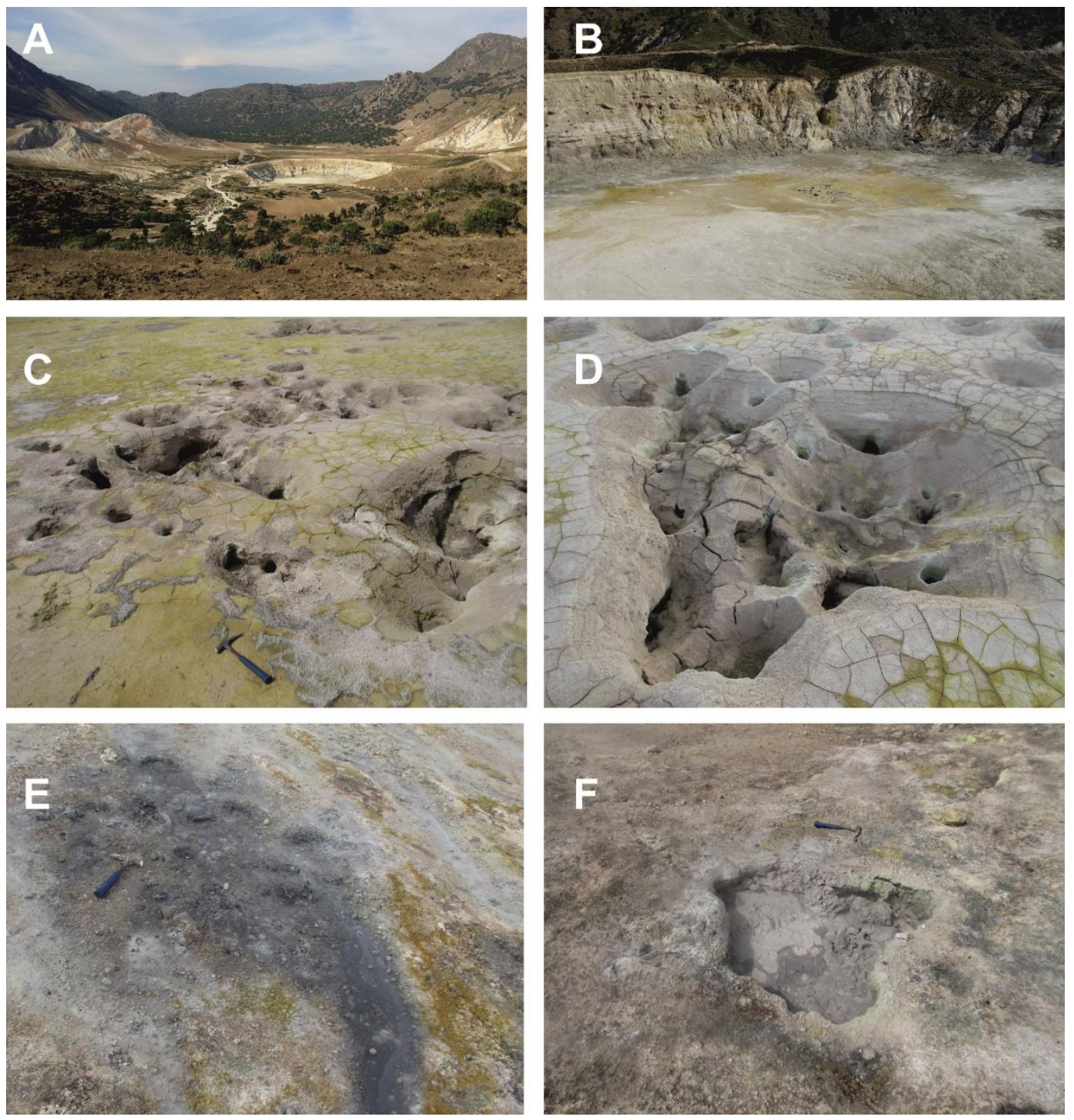

Figure 2 - (A) General view of the Nisyros caldera from the North. (B) General view of the Stefanos hydrothermal crater, with characteristic white-yellowish altered rocks. (C) and (D) Dry mudpots. (E) Steaming ground with limited water supply. (F) Active boiling mudpot. 

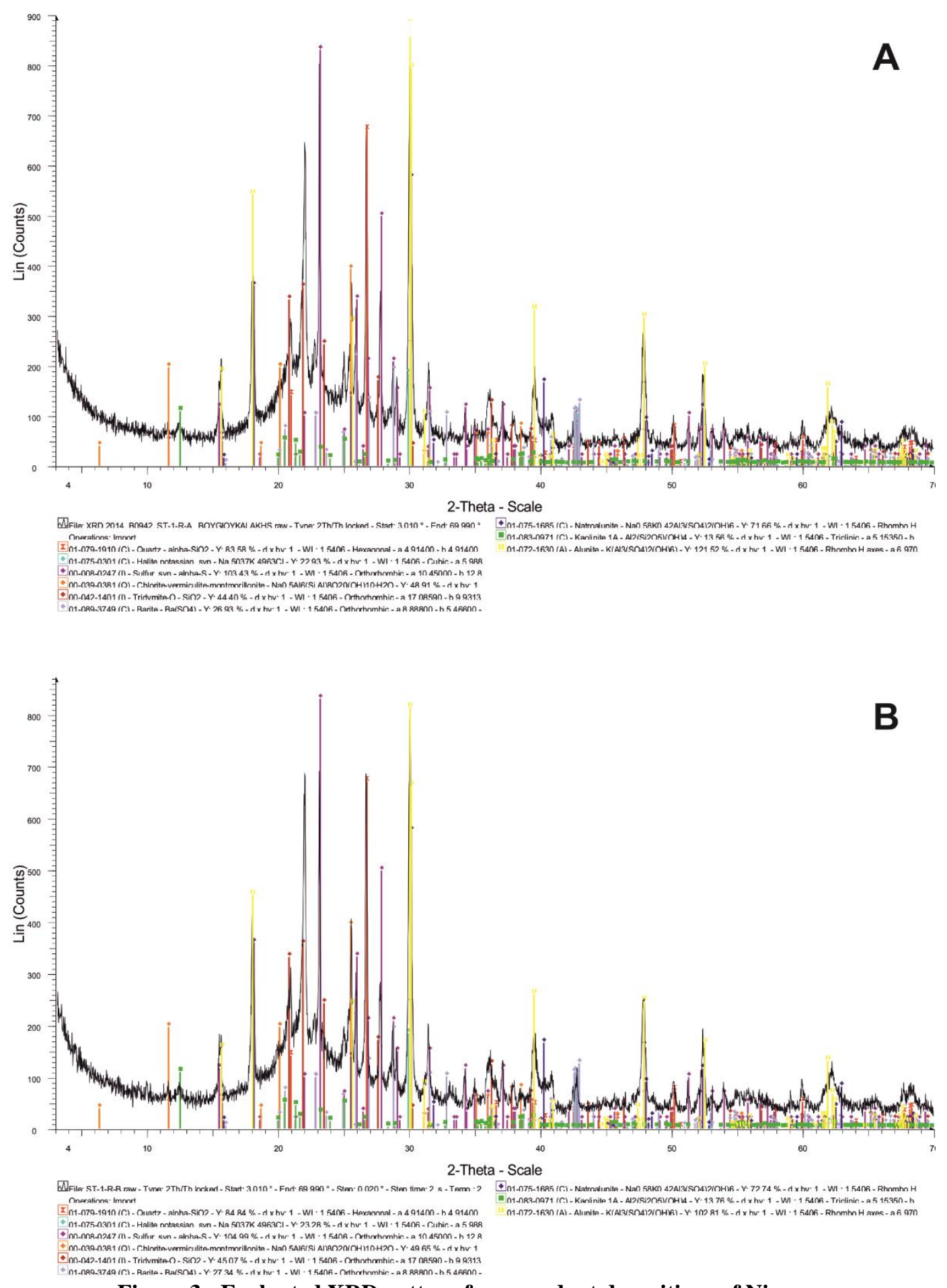

Figure 3 - Evaluated XRD pattern from mudpot depositions of Nisyros. 


\begin{tabular}{|c|c|c|c|c|c|c|}
\hline \multicolumn{3}{|c|}{$\begin{array}{l}\text { Table } 1 \text { - Concentrations of major and } \\
\text { trace elements in water sample. }\end{array}$} & \multicolumn{4}{|c|}{$\begin{array}{c}\text { Table } 2 \text { - Concentrations of major and trace } \\
\text { elements in deposition samples. }\end{array}$} \\
\hline \multicolumn{3}{|c|}{ ST-1-W } & \multicolumn{3}{|r|}{ ST-1-A-R } & \multirow{2}{*}{\begin{tabular}{|c|} 
ST-1-B-R \\
52.65
\end{tabular}} \\
\hline pH & & 2.4 & $\mathrm{SiO}_{2}$ & $\%$ & 52.35 & \\
\hline Al & $\mathrm{mg} / \mathrm{L}$ & 72 & $\mathbf{A l}_{2} \mathrm{O}_{3}$ & $\%$ & 1.95 & 2 \\
\hline & & & $\mathrm{Fe}_{2} \mathrm{O}_{3}$ & $\%$ & 0.25 & 0.15 \\
\hline Ca & $\mathrm{mg} / \mathrm{L}$ & 190 & $\mathrm{CaO}$ & $\%$ & 0.1 & 0.1 \\
\hline Mg & $\mathrm{mg} / \mathrm{L}$ & 10.1 & MgO & $\%$ & $<0,01$ & $<0,01$ \\
\hline $\mathbf{N a}$ & $\mathrm{mg} / \mathrm{L}$ & 21.2 & $\mathrm{TiO}_{2}$ & $\%$ & 0.25 & 0.25 \\
\hline $\mathbf{K}$ & $\mathrm{mg} / \mathrm{L}$ & 2.74 & MnO & $\%$ & $<0,01$ & $<0,01$ \\
\hline $\mathrm{K}$ & Ing/L & 2.14 & $\mathrm{~K}_{2} \mathrm{O}$ & $\%$ & 1.6 & 1.55 \\
\hline $\mathrm{HCO}_{3}$ & $\mathrm{mg} / \mathrm{L}$ & bld & $\mathrm{Na}_{2} \mathrm{O}$ & $\%$ & 1.8 & 0.95 \\
\hline Cl & $\mathrm{mg} / \mathrm{L}$ & 4.25 & $\mathbf{S}$ & $\%$ & 14.7 & 14.7 \\
\hline $\mathrm{SO}_{4}$ & $\mathrm{mg} / \mathrm{L}$ & 1375 & L.O.I. & $\%$ & 26.7 & 26.7 \\
\hline $\mathrm{NO}_{2}$ & $\mathrm{mg} / \mathrm{L}$ & $<0,050$ & $\mathbf{V}$ & $\mathbf{m g} / \mathrm{Kg}$ & 92 & 86 \\
\hline $\mathrm{NO}_{3}$ & $\mathrm{mg} / \mathrm{L}$ & $<5,0$ & $\mathrm{Cr}$ & $\mathrm{mg} / \mathrm{Kg}$ & 56 & 60 \\
\hline $\mathrm{NH}_{4}$ & $\mathrm{mg} / \mathrm{L}$ & 70.5 & Co & $\mathrm{mg} / \mathrm{Kg}$ & 1 & 1 \\
\hline $\mathrm{SiO}_{2}$ & $\mathrm{mg} / \mathrm{L}$ & 277 & $\mathbf{N i}$ & $\mathrm{mg} / \mathrm{Kg}$ & 14 & 16 \\
\hline Ag & $\mu \mathrm{g} / \mathrm{L}$ & $<5$ & $\mathrm{Cu}$ & $\mathrm{mg} / \mathrm{Kg}$ & 72 & 44 \\
\hline As & $\mu \mathrm{g} / \mathrm{L}$ & $<100$ & $\mathbf{Z n}$ & $\mathrm{mg} / \mathrm{Kg}$ & 35 & 29 \\
\hline B & $\mu \mathrm{g} / \mathrm{L}$ & 41 & As & $\mathrm{mg} / \mathrm{Kg}$ & 37 & 22 \\
\hline $\mathbf{B a}$ & $\mu \mathrm{g} / \mathrm{L}$ & 16 & $\mathbf{R b}$ & $\mathrm{mg} / \mathrm{Kg}$ & 12 & 18 \\
\hline Be & $\mu \mathrm{g} / \mathrm{L}$ & $<5$ & $\mathrm{Sr}$ & $\mathrm{mg} / \mathrm{Kg}$ & 300 & 275 \\
\hline $\mathbf{B r}$ & $\mu \mathrm{g} / \mathrm{L}$ & - & Mo & $\mathrm{mg} / \mathrm{Kg}$ & 5 & 5 \\
\hline Cd & $\mu \mathrm{g} / \mathrm{L}$ & $<5$ & Cd & $\mathrm{mg} / \mathrm{Kg}$ & $<1$ & $<1$ \\
\hline Co & $\mu \mathrm{g} / \mathrm{L}$ & $<10$ & $\mathbf{B a}$ & $\mathrm{mg} / \mathrm{Kg}$ & 1290 & 1150 \\
\hline $\mathrm{Cr}$ & $\mu \mathrm{g} / \mathrm{L}$ & 40 & $\mathbf{P b}$ & $\mathrm{mg} / \mathrm{Kg}$ & 430 & 400 \\
\hline $\mathbf{C u}$ & $\mu \mathrm{g} / \mathrm{L}$ & $<10$ & $\mathbf{U}$ & $\mathrm{mg} / \mathrm{Kg}$ & 1 & 1 \\
\hline $\mathbf{F}$ & $\mu \mathrm{g} / \mathrm{L}$ & 1340 & Sc & $\mathbf{m g} / \mathrm{Kg}$ & 7 & 7 \\
\hline $\mathbf{F e}$ & $\mu \mathrm{g} / \mathrm{L}$ & 55000 & $\mathbf{Y}$ & $\mathrm{mg} / \mathrm{Kg}$ & 7 & 7 \\
\hline Hg & $\mu \mathrm{g} / \mathrm{L}$ & $<0,5$ & La & $\mathrm{mg} / \mathrm{Kg}$ & 14 & 15 \\
\hline I & $\mu \mathrm{g} / \mathrm{L}$ & - & $\mathrm{Ce}$ & $\mathrm{mg} / \mathrm{Kg}$ & 26 & 27 \\
\hline $\mathbf{L i}$ & $\mu \mathrm{g} / \mathrm{L}$ & 11 & Pr & $\mathrm{mg} / \mathrm{Kg}$ & 3 & 3 \\
\hline Mn & $\mu \mathrm{g} / \mathrm{L}$ & 190 & Nd & $\mathrm{mg} / \mathrm{Kg}$ & 10 & 10 \\
\hline Mo & $\mu \mathrm{g} / \mathrm{L}$ & $<10$ & $\mathrm{Sm}$ & $\mathrm{mg} / \mathrm{Kg}$ & 3 & 3 \\
\hline $\mathbf{N i}$ & $\mu \mathrm{g} / \mathrm{L}$ & 26 & Eu & $\mathrm{mg} / \mathrm{Kg}$ & 1 & 1 \\
\hline $\mathbf{P b}$ & $\mu \mathrm{g} / \mathrm{L}$ & 9 & Gd & $\mathrm{mg} / \mathrm{Kg}$ & 2 & 2 \\
\hline $\mathbf{R b}$ & $\mu \mathrm{g} / \mathrm{L}$ & 60 & Tb & $\mathrm{mg} / \mathrm{Kg}$ & $<1$ & $<1$ \\
\hline Sb & $\mu \mathrm{g} / \mathrm{L}$ & $<5$ & Dy & $\mathrm{mg} / \mathrm{Kg}$ & 1 & 1 \\
\hline Se & $\mu \mathrm{g} / \mathrm{L}$ & 11 & Ho & $\mathrm{mg} / \mathrm{Kg}$ & $<1$ & $<1$ \\
\hline $\mathrm{Sr}$ & $\mu \mathrm{g} / \mathrm{L}$ & 480 & $\mathbf{E r}$ & $\mathrm{mg} / \mathrm{Kg}$ & $<1$ & $<1$ \\
\hline $\mathbf{U}$ & $\mu \mathrm{g} / \mathrm{L}$ & $<5$ & $\mathbf{T m}$ & $\mathrm{mg} / \mathrm{Kg}$ & $<1$ & $<1$ \\
\hline $\mathbf{V}$ & $\mu \mathrm{g} / \mathrm{L}$ & 120 & Yb & $\mathrm{mg} / \mathrm{Kg}$ & $<1$ & $<1$ \\
\hline $\mathbf{Z n}$ & $\mu \mathrm{g} / \mathrm{L}$ & 19500 & $\mathbf{L u}$ & $\mathrm{mg} / \mathrm{Kg}$ & $<1$ & $<1$ \\
\hline & & & Th & $\mathrm{mg} / \mathrm{Kg}$ & 5 & 5 \\
\hline
\end{tabular}




\section{Analytical results}

The analysed chemical parameters are presented in Table 1 and 2 . The studied water sample is very acidic $(\mathrm{pH}=2.4)$ with high concentration of sulfate $(1375 \mathrm{mg} / \mathrm{L})$, silica $(277 \mathrm{mg} / \mathrm{L} \mathrm{SiO} 2)$, calcium $(190 \mathrm{mg} / \mathrm{L})$ and aluminum $(72 \mathrm{mg} / \mathrm{L})$. It presents also high concentrations of metallic elements like Fe $(55 \mathrm{mg} / \mathrm{L})$ and $\mathrm{Zn}(19.5 \mathrm{mg} / \mathrm{L})$.

The mineralogical and geochemical compositions of depositions, from the active and dry mudpots, are similar. The mineralogical composition of the depositions is quartz, tridymite, alunite, elemental sulfur, chlorite-vermiculite-montorillonite, kaolinite, barite and halite (Fig. 3). The bulk geochemical analysis (Table 2) of the studies depositions shown high concentrations to major elements like $55 \%$ to $\mathrm{SiO}_{2}$ and $14.7 \%$ to $\mathrm{S}$ and between 1 to $2 \%$ to $\mathrm{Al}_{2} \mathrm{O}_{3}, \mathrm{~K}_{2} \mathrm{O}$ and $\mathrm{Na}_{2} \mathrm{O}$. High concentrations were found in a series of trace elements and some REE like $\mathrm{Pb}$ (up to $430 \mathrm{mg} / \mathrm{Kg}$ ), $\mathrm{Cu}$ (up to $72 \mathrm{mg} / \mathrm{Kg}$ ), Cr (up to $60 \mathrm{mg} / \mathrm{Kg}$ ), As (up to $37 \mathrm{mg} / \mathrm{Kg}$ ), $\mathrm{Zn}$ (up to $35 \mathrm{mg} / \mathrm{Kg}$ ), Ni (up to $16 \mathrm{mg} / \mathrm{Kg}$ ), Ce (up to $27 \mathrm{mg} / \mathrm{Kg}$ ), La (up to $15 \mathrm{mg} / \mathrm{Kg}$ ), $\mathrm{Nd}$ (up to $10 \mathrm{mg} / \mathrm{Kg}$ ) and $\mathrm{Th}$ (up to 5 $\mathrm{mg} / \mathrm{Kg})$.

\section{Discussion - conclusions}

Nisyros Island is young composite volcano with a central caldera. Underneath, it develops a hydrothermal system, with circulation of meteoric and sea water. Surface manifestations of the hydrothermal system are the hot springs, the fumaroles, the hydrothermal craters, the hot grounds and the mudpots. The present study shows and evaluates for the first time the chemical composition of the active mudpots of Nisyros and the mineralogical and geochemical composition of their depositions.

On Nisyros, meteoric and sea water goes deep underground using permeable rock, fractures, fault systems and boundaries between volcanic flows. Once deep underground, the water is heated. The heat source is a body of magma or a body of solid but still very hot rock related to recent quite active volcanism. This heat source is probably located at a depth of 4-6 km. When water penetrates the hot rock surrounding the heat source, it is heated by conduction. Hydrochloric acid, sulfurous gases and other volatiles emitted by the body of magma or hot rock dissolve in the water as it is heated. Because it is less dense than cold water, the heated water rises by convection. As the water rises, acids react with surrounding rocks, enriching the water in dissolved silica $\left(\mathrm{SiO}_{2}\right)$ and metals. The chemically evolving hot water rises, where it saturates permeable rock and accumulates in fractures beneath the thermal features creating a geothermal reservoir. Based on the two deep geothermal wells drilled on the island by PPC (Public Power Company, Geotermica Italiana, 1983, 1984; Marinelli et al., 1983; Chiodini et al., 1993) two main hot aquifers were identified. The first one in $\sim 250-700 \mathrm{~m}$ and the second one from $\sim 1000$ to $1500 \mathrm{~m}$ depth, with temperatures $120-180{ }^{\circ} \mathrm{C}$ and $290{ }^{\circ} \mathrm{C}$ respectively (Marini et al., 1993; Ambrosio et al., 2010).

When rising hot water reaches a depth where the pressure of overlying fluid (hydrostatic pressure) has decreased, boiling occurs. Bubbles of steam rise through the water and migrate to the surface, carrying most of the gases that were dissolved in the water (carbon dioxide, hydrogen sulfide, hydrogen, nitrogen and helium).

Steam and non-condensable gasses reaches the surface through fractions and creates the fumaroles. It may also condense and heat groundwater near the surface. The condensed steam and heated water may boil at the water table, creating the boiling mudpots. Hydrogen sulfide gas is oxidized in this near-surface, oxygen-rich environment to form elemental sulfur and sulfuric acid, producing waters that are acidic (low $\mathrm{pH}$ ) and have a high sulfate concentration. Stefanos mudpots water have $\mathrm{pH}=$ $2.4,1375 \mathrm{mg} / \mathrm{L}$ of sulfate and temperature near the boiling point. Also, hydrogen sulfide gas is one of the main components of the fumaroles in Nisyros volcano (Teschner et al., 2005; Tassi et al., 2013). For that reason, also the studied water present very high sulfate concentration $(1375 \mathrm{mg} / \mathrm{L})$ and crystals of elemental sulfur found inside the studied depositions. The water is also enriched in 
dissolved silica (277 mg/L SiO 2 ) and metals (e.g. $55 \mathrm{mg} / \mathrm{L} \mathrm{Fe} ; 19.5 \mathrm{mg} / \mathrm{L} \mathrm{Zn}$ ). High concentrations of major and trace elements like Ca $(190 \mathrm{mg} / \mathrm{L}), \mathrm{Al}(72 \mathrm{mg} / \mathrm{L}), \mathrm{Sr}(480 \mu \mathrm{g} / \mathrm{L})$ etc reflecting the alterations processes which are taking place.

Inside Stefanos hydrothermal crater characteristic is the view of white-yellow altered rocks (Fig. 2A, B, C). Hydrothermal alteration occurs when acidic hot water chemically changes minerals in rocks. The final product of such alteration in volcanic rocks is usually white material rich in kaolinite clay and silica; this material is abundant at Nisyros caldera and especially at Stefanos hydrothermal crater. More specifically, the mineralogical study reveals that the studied depositions comprise of quartz, tridymite, alunite, elemental sulfur, chlorite-vermiculite-montorillonite, kaolinite, barite and halite as main mineral phases. In agreement to the mineralogical results are the results of the chemical analysis. The highest concentrations are presented to $\mathrm{SiO}_{2}$ and $\mathrm{S}(52 \%$ and $14.7 \%$ respectively) and follow $\mathrm{Al}_{2} \mathrm{O}_{3}, \mathrm{~K}_{2} \mathrm{O}$ and $\mathrm{Na}_{2} \mathrm{O}$ with concentrations between 1 to $2 \%$. It is interesting the enrichment of the depositions in metals like $\mathrm{Pb}$ (up to $430 \mathrm{mg} / \mathrm{Kg}$ ), $\mathrm{Cu}$ (up to $72 \mathrm{mg} / \mathrm{Kg}$ ), $\mathrm{Cr}$ (up to $60 \mathrm{mg} / \mathrm{Kg}$ ), As (up to $37 \mathrm{mg} / \mathrm{Kg}$ ), Zn (up to $35 \mathrm{mg} / \mathrm{Kg}$ ), Ni (up to $16 \mathrm{mg} / \mathrm{Kg}$ ) and in some REE like Ce (up to $27 \mathrm{mg} / \mathrm{Kg}$ ), $\mathrm{La}$ (up to $15 \mathrm{mg} / \mathrm{Kg}$ ), $\mathrm{Nd}$ (up to $10 \mathrm{mg} / \mathrm{Kg}$ ) and Th (up to $5 \mathrm{mg} / \mathrm{Kg}$ ).

Even though the presented data are limited, allow as insights of the hydrothermal processes of Nisyros volcano. In order to have a better picture, a further more systematic study of the mudpots is needed i.e. including chemical and isotopic analysis of the gas and isotopic analysis of the water. Several studies have conducted concerning Nisyros, but still many open questions remain to be answered. More data concerning the reservoir, the circulation and the composition of the fluid below the surface will be valuable. They could reveal the detail hydrothermal processes which are taking place and allow us to compare them with old-not active systems, estimate geothermal potentials of the system etc. Also, the surface manifestations of the system create an extreme environment in which unstudied geological and biological processes take place alongside.

\section{Acknowledgements}

This study was funded by the National Strategic Reference Framework (NSRF, 350913). The authors would like to thank Dr. George Vougioukalakis who critically commented on an earlier version of this manuscript and the local population for their co-operation during the field work.

\section{References}

Ambrosio, M., Doveri, M., Fagioli, M., Marini, L, Principe, C. and Raco, B., 2010. Water-rock interaction in the magmatic-hydrothermal system of Nisyros Island (Greece), J. Volcanology and Geothermal Research, 192, 57-68.

Bohla, M. and Keller, J., 1987. Petrology of plinian eruptions of Nisyros volcano, Hellenic arc, Terra cognita, 7, $171 \mathrm{pp}$.

Bohla, M. and Keller, J., 1987. Petrology of Plinian eruptions of Nisyros volcano, Hellenic Arc, Terra Cognita, 7, 171.

Bonadonna, C., Ernst, G.G.J. and Sparks, R.S.J., 1998. Thickness variations and volume estimates of tephra fall deposits: the importance of particle Reynolds number, Journal of Volcanology and Geothermal Research, 81, 173-187.

Caliro, S., Chiodini, G., Galluzzo, D., Granieri, D., La Rocca, M., Saccorotti, G. and Ventura, G., 2005. Recent activity of Nisyros volcano (Greece) inferred from structural, geochemical and seismological data, Bull. Volcanol., 67, 358-369.

Chiodini, G., Brombach, T., Caliro, S., Cardellini, C., Marini, L. and Dietrich, V., 2002. Geochemical indicators of possible ongoing volcanic unrest at Nisyros Island (Greece), Geophys. Res. Lett., 29(16), doi: 10.1029/2001GL014355.

Clynne, M.A., Janik, C.J. and Muffler, L.P., 2003. "Hot Water" in Lassen Volcanic National ParkFumaroles, Steaming Ground, and Boiling Mudpots, U.S. Geological Survey Fact Sheet, 101$02,4 \mathrm{pp}$. 
Di Paola, G.M., 1974. Volcanology and petrology of Nisyros Island (Dodecanese, Greece), Bull. Volcanol., 38, 944-987.

Federman, A.N. and Karey, S.N., 1980. Electron microprobe correlation of tephra layers from Eastern Mediterranean abyssal sediments and the Island of Santorini, Quat.Res., 13, 160-171.

Francalanci, L., Varekamp, J.C., Vougioukalakis, G., Defant, M.J., Innocenti, F. and Manetti, P., 1995. Crystal retention, fractionation and crustal assimilation in a convecting magma chamber, Nisyros Volcano, Greece, Bull. Volcanol., 56, 601-620.

Gansecki, C., 1991. Petrology of the domes and inclusions of Nisyros volcano, Dodecanese island, Greece, BA Thesis, Wesleyan University, Middletown, CT, 97 pp.

Geotermica Italiana, 1983. Nisyros 1 geothermal well, Unpublished PPC-EEC report, 106 pp.

Geotermica Italiana, 1984. Nisyros 2 geothermal well, Unpublished PPC-EEC report, 44 pp.

Gorceix, M.H., 1873. Sur l' eruption boueuse de Nisyros, Centre de Recherche Academie de Paris, LXXVII(X, XI, XII), 1474-1477.

Gorceix, M.H., 1874. Sur l'etude des fumerolles de Nisyros et de quelques-uns des produits de l'eruption de 1873, Centre de Recherche Academie de Paris, LXXVIII(X,XII), 1309-1311.

Keller, J., 1971. The major volcanic events in recent eastern mediterranean volcanism and their bearing on the problem of Santorini ash layers, Int. Sci. Congr. Volcano Thera, 1, 152-169.

Keller, J., Rehren, T. and Stadlbauer, E., 1990. Explosive volcanism in the Hellenic Arc: a summary and review. In: Hardy, D.A., Keller, J., Galanopoulos, V.P., Flemming, N.C. and Druitt, T.H., eds., Thera and the Aegean World, Proc. 3d Int. Congr., The Thera Foundation, 13-26.

Kinvig, H.S., Winson, A. and Gottsmann, J., 2010. Analysis of volcanic threat from Nisyros Island, Greece, with implications for aviation and population exposure, Natural Hazards Earth System Sciences, 10, 1101-1113.

Limburg, E.M., 1986. Young pyroclastics on Nisyros, Greece: Physical studies, B.A. thesis, Wesleyan Un., Middletown, CT, 104 pp.

Limburg, E.M., Lodice, L. and Varekamp, J.C., 1986. Volcanology and Petrology of Nisyros, Greece. In: Sigurdson,H., Ed., Enviromental Impact of Volcanism, Norman Watkins Symposium, Un. of Rhode Island, Narrangansett, RI, 47-49.

Limburg, E.M. and Varekamp, J.C., 1991. Young pumice deposits on Nisyros, Greece, Bull. Volc. 54, 68-77.

Lodise, L., 1987. Petrology and geochemistry of Nisyros volcano (Dodecanese, Greece), MS Thesis, Wesleyan University, Mddletown, CT, USA, 245 pp.

Marini, L., Peincipe, C., Chiodini, G., Cioni, R., Fytikas, M. and Marinelli, G., 1993. Hydrothermal eruptions of Nisyros (Dodecanese, Greece). Past events and present hazard, J. Volc. And Geothermal Research, 56, 71-94.

Martelli, A., 1917. Il gruppo eruttivo di Nisiro nel mare Egeo, Societa dei XL, ser. 3, XX, 79-165.

Papanikolaou, D.J., Lekkas, E.L. and Sakellariou, D., 1991. Geological structure and evolution of the Nisyros Volcano, Bull. Geol. Soc. Greece XXV, 405-419 (In Greek, with English abstract).

Rehren, T., 1988. Geochemie und Petrologie von Nisyros, PhD thesis. Univ. Freiburg.

Seymour, K. and Vlassopoulos, D., 1992. Magma mixing at Nisyros volcano, as inferred from incompatible trace-elements systematics, J. Volcanol. Geotherm. Res., 50, 273-299.

Shimizu, A., Sumino, H., Nagao, K., Notsu, K. and Mitropoulos, P., 2005. Variation in noble gas isotopic composition of gas samples from the Aegean arc, Greece, J. Volcanol. Geotherm. Res., 140, 321-339.

Tassi, F., Vaselli, O., Papazachos, C.B., Giannini, L., Chiodini, G., Vougioukalakis, G.E., Karagianni, E., Vamvakaris, D. and Panagiotopoulos, D., 2013. Geochemical and isotopic changes in the fumarolic and submerged gas discharges during the 2011-2012 unrest at Santorini caldera (Greece), Bulletin of Volcanology, 75, 711.

Teschner, M., Vougioukalakis, G.E., Faber, E., Poggenburg, J. and Hatziyannis, G., 2005. Real time monitoring of gas-geochemical parameters in Nisyros fumaroles. In: Developments in Volcanology, 7, 247-254. 
Varekamp, J.C.R., Kreulen, R., Poorter, R.P.E. and Van Bergen, M.J., 1992. Carbon sources and arc volcanism, with implications for the carbon cycle, Terra Nova, 4(3), 363-373, doi: 10.1111/j .1365-3121.1992.tb00825.x.

Volentik, A., Vanderkluysen, L. and Principe, C., 2002. Stratigraphy of the caldera walls of Nisyros volcano, Greece, Eclogae Geol. Helv., 95, 223-235.

Vougioukalakis, G. and Androulakakis, N., 2008. Presenting the Volcano of Nisyros. http://nisyros.igme.gr/nisyros/index.php?option=com_content\&task=view\&id=12\&Itemid=26, Athens, IGME.

Vougioukalakis, G., 1984. Studio vulcanologico e chimico-petrografico dell'isola di Nisyros (Dodecanneso, Grecia), Tesi di laurea, Universita di Pisa.

Vougioukalakis, G., 1998. Blue volcanoes: Nisyros, Regional Council of Mandraki.

Vougioukalakis, G.E., 1993. Volcanic stratigraphy and evolution of Nisyros Island, Bull. Geol. Soc. Greece, XXVII, 239-258 (In Greek, with English abstract).

Wyers, G.P. and Barton, M., 1989. Polybaric evolution of calc-alkaline magmas from Nisyros, Southeastern Hellenic Arc, Greece, J. Petrol., 30, 1-37. 